\title{
A Magnificent Gift: Jan Patocka and Vaclav Havel on Dissident Sacrifice
}

\author{
Daniel Brennan ${ }^{1}$
}

The paper compares and contrasts Jan Patočka and Vaclav Havel's respective thoughts on dissent. Using Aristotle's thoughts on the magnanimous man as a sounding board, the paper argues with Patočka that dissent is best undertaken as a gift to a community made with sound philosophical reflection. The paper also argues with Havel that dissent is also a task for every citizen who is caught in an oppressive political situation -that is dissent is not the sole responsibility of the reflective philosopher but every citizen whose actions contribute to the sustenance of ideology. [Article copies available for a fee from The Transformative Studies Institute. E-mail address:_journal@transformativestudies.org Website: http://www.transformativestudies.org (02017 by The Transformative Studies Institute. All rights reserved.]

KEYWORDS: Dissent, Sacrifice, Jan Patočka, Vaclav Havel, Phenomenology.

\section{INTRODUCTION}

In considering the meaning of a dissident sacrifice, there is a tendency to associate the meaning of the act with how the public receives the sacrifice. For example, the self-immolation of an individual, if it incites a riot, is remembered and praised; if it receives no public attention, then those who hear of it may say 'what a waste'. How a public perceives a

\footnotetext{
${ }^{1}$ Daniel Brennan, Ph.D., is an early career researcher at Bond University. His Ph.D. thesis was titled, A Reappraisal of the Political Philosophy of Vaclav Havel. He currently lectures in ethics and critical thinking. Daniel has an upcoming book with Brill publications, The Political Philosophy of Vaclav Havel. He has also published on the dissident philosophy of Jan Patočka and Vaclav Havel as well as having articles currently under review on film philosophy, feminist critique of social institutions, embodied existence under oppressive social systems, art as political action, and social ontology. Daniel's main research area lies in the role that individual action plays in the creation of a political situation. Address correspondence to: Dr. Daniel Brennan, Bond University, 14 University Drive, Robina QLD 4226, Australia; e-mail: dbrennan@bond.edu.au.
} 